\title{
Two decades of re-aligning mundane entrepreneurship in Cuba
}

\section{Dos décadas de realineación del emprendimiento cotidiano en Cuba}

\author{
Joseph L. SCARPACI* \\ Ted A. Henken** \\ ArChibald R. M. RitTer ${ }^{* * *}$
}

\begin{abstract}
We examine how small entrepreneurs perceive their changing internal and external environments in Cuba, a country with a highly regulated yet emerging entrepreneurial class. We build on the concept of everyday exchange or mundane entrepreneurship, originally developed as a lens to understand non-state actions in the former USSR, and apply it to contemporary Cuba in the post-Soviet era. Our socially situated case of entrepreneurship in Cuba identifies how entrepreneurial behavior is sustained outside the contexts of the market. The result is a realignment in which contemporary entrepreneurship on the island shares important similarities with the Soviet blat system, while it also exhibits attributes that are unique to the Cuban case.
\end{abstract}

Keywords: mundane entrepreneurship, self-employment, underground economy, SMEs, Cuba.

\section{Resumen}

El presente trabajo examina cómo los pequeños empresarios en Cuba perciben sus entornos internos y externos en un país que regula fuertemente la emergencia de una clase empresarial. Partimos del concepto de intercambios cotidianos o emprendimiento mundano que fue desarrollado originalmente en la ex Unión Soviética, como un lente para comprender el comportamiento de los actores no estatales tanto en Cuba como en la ex Unión Soviética. Nuestro estudio de caso se enmarca en un contexto social e identifica cómo los empresarios cubanos se sostienen fuera del mercado. El resultado es un reajuste en el cual el emprendimiento cubano muestra varias características similares al sistema soviético llamado blat; al mismo tiempo que revela atributos que le son únicos.

Palabras claves: emprendimiento cotidiano, el autoempleo, la economía subterránea, PyMES, Cuba.

* Center for the Study of Cuban Culture and the Economy, USA, email: joescarpaci@gmail.com

** Department Black and Latino Studies at Baruch College, University of New York, USA, email: t_henken@yahoo.com

*** Department of Economics and the Norman Paterson School of International Affairs at Carleton University. Canada, email: ArchRitter@cunet.carleton.ca 


\section{Introduction}

Post-cold war entrepreneurship research contends that market economy and entrepreneurship are essential forces in sustaining centrally planned, or "command" economies, even as those states have periodically attempted to outlaw such forces. Such logic assumes entrepreneurship is an "exogenous" variable, one "thing" that is introduced into a society from the outside. However, there is growing evidence that flexible opportunity networks function within command economies despite (or perhaps because of) the rigidity of state planning.

Rehn and Taalas (2004) outlined this phenomenon in their review of everyday exchange or mundane entrepreneurship in the Soviet Union. The authors claim that "the Union of the Soviet Socialist Republics might be seen as the most entrepreneurial society ever [...] [because it] forced all citizens to become micro-entrepreneurs [...] in even the most mundane facets of everyday life" (Rehn and Taalas 2004: 237; emphasis in the original).

The case of the blat, or the economy of favors, sustained the former USSR in ways previously unrecognized. Omitting studies of entrepreneurship in command economies may result from the idea in modern economic and political literatures that the entrepreneurial spirit can only survive in market economies. Rehn and Taalas (2004: 236) outline this conceptual dilemma in this way: "[w]e tend to look at successful societies or regions and proclaim these as entrepreneurial on the basis they exhibit results we assume might follow from entrepreneurialism - reductio ad absurdum". This paper builds on this notion of everyday exchange or mundane entrepreneurship by examining Cuba in the post-Soviet era (roughly 1990-present). In doing so, we provide a socially situated case of entrepreneurship in Cuba and aim to contribute to how everyday or mundane entrepreneurship can be sustained outside the contexts of the market and business as market economies define them. Our reference to Cuba's "entrepreneurial realignment" derives in part from the Cuban Communist Party's Sixth Congress held in April 2011, in which they issued a series of guidelines ("lineamientos," or aligning principles) aimed at adjusting the socialist model to confront the current economic crisis at home and globally. However, we also chronicle a simultaneous and more organic bottom-up economic realignment initiated through everyday economic practices (i.e., mundane entrepreneurship) of Cuba's cuentapropistas (self-employed workers).

We show that while the nature of entrepreneurship, its challenges and opportunities are unique in Cuba, this entrepreneurship also shares important similarities with the Soviet blat system and that the phenomenon 
derives as much from the internal contradictions and pressures inherent to command economies as it does from external influence and models. We draw on original survey research from three key periods $-1998,2008$, and 2011- that assesses how budding entrepreneurs tackle small business challenges.

Entrepreneurship in Cuba has undergone substantial realignment since the beginning of the post-Soviet era around 1990. Dubbed the 'Special Period in Times of Peace' or simply the 'Special Period' by Fidel Castro at the time, this era ushered in fresh opportunities for Cuban entrepreneurs, with the decriminalization of the dollar in late 1993, incentives to attract foreign investment through joint ventures, and the legalization of a limited number of private occupations (Cepal, 1997; Pérez-López, 1994; Pérez-López, 2001).

The literature on Cuban entrepreneurship highlights obstacles for these self-employed workers, where the state still looms large over entrepreneurial activity (Peters and Scarpaci, 1998; Ritter, 1998; Elinson, 1999; Cruz and Villamil, 2000; Trumbull, 2001; Henken, 2002; Scarpaci, 2002; Osborn and Wenger, 2005; Phillips, 2007; Ritter and Henken, 2014). Thus, the movement away from the Soviet influence seemed to simultaneously liberalize and tighten the regulatory environment in which Cuban entrepreneurs operate (Pérez-López, 1995). Even amidst the unprecedented economic reforms enacted under Raúl Castro since 2008, the official government policy continues to aim at the "perfecting of socialism" (Zawadski, 2009) and 'perfecting businesses' (perfeccionamiento empresarial) (Morales and Scarpaci, 2012: 29), so far refusing to fully legitimize the role of the private sector, the market mechanism, or small- and medium-sized enterprise in Cuba's economic realignment.

\section{Background literature}

\subsection{The cuban economy since 1959}

By 1958, Cuba had a large private sector, mainly national, although with a strong foreign presence; a significant state sector; and some "benevolent associations" operated in the cooperative sector. The Cuban Revolution's nationalizations between 1959 and 1961 eliminated most of the private sector and the older cooperative sector, the impact of which is well known (Gordon, 1976). In 1959, nearly 60,000 retail outlets operated in Cuba but it dropped by two-thirds within a decade (Morales and Scarpaci, 2012: 20-23).

The 1968 'Revolutionary Offensive' entailed the complete seizure of Cuba's smallest remaining private businesses: hot-dog carts, repair shops, 
vegetable stands, snack shops, and the like. Without legal recourse, these petty trades were driven underground or out of business (Cruz and Villamil, 2000). Replacing the services that these vendors had provided was a tremendous challenge for the Cuban state in the 1970s (Scarpaci et al. 2002), as it was far less responsive to customer needs and terribly inefficient. Ever enterprising, Cuban citizens relied on an expansive black market for many goods and services traditionally provided by small businesses. It is common today in most Cuban households to have at least one adult -often a retired or un-(under-)employed member- who actively scouts the black market in search of cooking oil, bread, and other staples. Like the Soviet blat system, Cubans have long relied on a buddy or crony system facetiously referred to as socio-lismo, playing off the $\mathrm{Cu}$ ban term for buddy or associate (socio) and socialismo, or socialism (León, 1995; Ritter, 1974).

The vicissitudes of these tepid private-sector policies underscore a perennial weakness of the island's state-planning system. Economic goals are plan-directed, resistant to change, and ideologically construed. As Pérez-López (1995: 96) notes:

Attaining economic objectives often demands that managers of state enterprises set low production goals, build wasteful inventories to avoid chronic supply problems, rely on personal favors, bribes and kickbacks to make ends meet, ignore cost and environmental restrictions; produce low-quality outputs, and falsify statistical performance reports.

Hernández-Reguant's recent anthropological work (2009) vividly illustrates that this characterization of the Cuban economy remains valid today: as the state begins to incorporate capitalist strategies, it has created two key concerns. First, economic disparities within the population have risen and are more pronounced than ever. Second, the state takes advantage of these disparities by promoting the sale of Cuban products, and thus earning much-needed hard currency (Scarpaci, 2010). By the late 1990s it became evident that relatively high amounts of market-based wealth and power began to concentrate in the hands of a small group of people, especially in economically expanding sectors such as those catering to tourists (Dilla, 2001).

The term 'Special Period' was coined by Fidel Castro in 1990 to refer to the draconian cutbacks caused by the loss of favorable terms of trade when the Soviet-bloc trading group, the Council for Mutual Economic Assistance (CMEA, or Comecon, founded in 1949), dissolved. Before the Special Period, management was reliant on centralization, five-year planning, and regulation focused on punitive measures for violators (Cunha 
and Campos e Cunha, 2003). The origins of these entrepreneurial shifts lie in the Special Period, to which we turn in the following section.

\subsection{Brief history of self-employment in Cuba}

Self-employment quickly disappeared in the first decade of the Cuban revolution as the government nationalized the principal means of production. Professions such as locksmiths, beauticians, upholsterers, and other single-worker enterprises characterized much of this work force. As noted earlier, though, the legalization of the dollar in 1993 moved in tandem with liberalizing work laws (Scarpaci, 1995). By 1996, the government reported approximately 150,000 workers (not quite 2 per cent of the labor force in Cuba at the time) as cuentapropistas. By 2007, the figure had shrunk to about 150,000 (figure 1) but has climbed to just under the half-million mark as of early 2015 .

Figure 1

Self-employed works in Cuba, 1994-2013 $\left({ }^{* 000 a)}\right.$

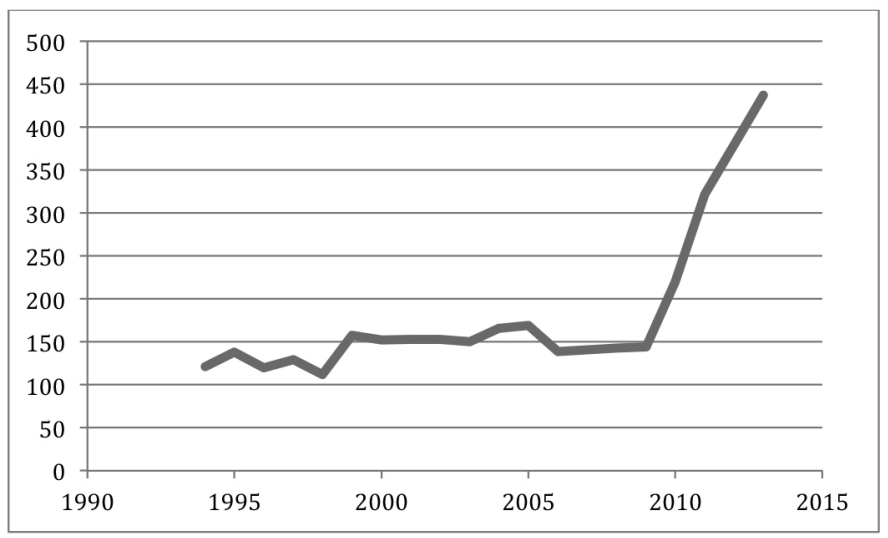

Data sources: Oficina Nacional de Estadística, Havana, República de Cuba.

The regulatory environment for these workers has long been shifting and convoluted, but it is tethered to the island's political economy in key ways (Mitnick 1980). Essentially, small businesses were outlawed in Cuba until recently, presumably because a nascent petite bourgeoisie threatened the socialist system. Home restaurants, for instance, could only employ family members and the number of chairs was limited to just 12 (though reforms in 2010 increased the number to 20, and to 50 in 2011). Certain foods such as lobster and beef were long prohibited from sale in these home restaurants (also rescinded in 2010). However, lookouts often 
alerted the operators of approaching state inspectors, thus allowing time to hide any wrongdoing.

The case of air pump operators is telling. With the collapse of favorable oil deals for sugar (between the USSR and Cuba), bicycle use soared throughout the island, from about 70,000 in 1989 to several hundred thousand a few years later (Scarpaci and Hall, 1995). Operating an air pump compressor to inflate tires soon became a common self-employment trade. Logically, the ability to patch tires is a parallel service in these settings, but during the 1993-2010 period the Cuban government prohibited the same air compressor operator from patching those same tires! Therefore, many households developed the strategy of having one family member secure a license for the air pump with another working as a tire patcher. Similar Cuban-style 'economies of favor' or blat are repeated across the island and among myriad trades and services, creating what might be considered small- and medium-sized enterprises (SMEs) elsewhere.

Operating a small business requires paying monthly licensing fees by the first of the month. Each municipality has a matrix of prices based on whether the self-employed worker charges in pesos or in hard currency (today called CUCs or convertible currency units). In the case of restaurants, if alcohol is served, then a hefty alcohol license is added to the monthly fee. Thus, a home restaurant in Havana's Plaza municipality catering largely to tourists and charging in hard currency and serving alcohol might be required to pay the equivalent of $\$ 800$ USD before the doors open at the first of each month (regardless of the operation's actual earnings). A similar facility, purportedly charging only in Cuban pesos in the same area, would pay only 400 pesos monthly (about \$16 USD).

Authorities can permanently withdraw a business license if any selfemployed worker fails to pay their monthly fee on time. Furthermore, there is no guarantee that the state will allow re-entry into the market. Seasonal work related to peak tourist arrival months is particularly challenging in this regard. Thus, bed-and-breakfast establishments, restaurants, bicycle-taxi operators, and related ancillary services must 'weather' the lean low season, and continue to pay licensure fees during the off-season. Such everyday experiences and mundane enterprises have become the daily bread of hundreds-of-thousands of Cubans -especially since the number of licensed cuentapropistas grew from 150,000 in October, 2010 to more than 450,000 in 2014 (ONE, 2013; Cubadebate, 2014; Feinberg, 2013). 


\subsection{Entrepreneurship: suppliers and customers}

Entrepreneurs are well known for their risk-bearing propensity and innovation. Much of the benchmark literatures (Schumpter 1942; Leibenstein 1968; Drucker 1958; Hofstede 2001; McClelland and Teague 1975) have treated entrepreneurship as an external variable and, a priori, dismiss its existence in centrally planned economies. In contrast, we claim that Cuba is quite entrepreneurial by starting with Schumpeter's notion of "creative destruction," in which the entrepreneur is cast as the principal disruptor who delivers change to moribund economies. The notion is admittedly somewhat reductionistic because it assumes that entrepreneurs are super-human, and their heroic make up leads to a modern economy and society.

One of the most frequent complaints of small entrepreneurs on the island today is the absence of a wholesale market (Cruz and Villamil, 2000). Peters and Scarpaci (1998) noted the problem five years into the cuentapropista experience, and as we report below, it is still prevalent today. The absence of wholesale trade markets is an important obstacle to small business development and an important impetus feeding the black market (Espinosa-Chepe and Henken, 2013). As Ritter observed long ago, restricted access to markets in Cuba is a real limitation for cuentapropistas (Ritter, 1998). Word of mouth, viral marketing, or possibly a write-up in a foreign tour guidebook or in-flight magazine can drive foot traffic to a private vendor. Today, with the advent of Internet sites like Trip Advisor, some Cuban entrepreneurs are attempting to overcome these obstacles using social media that is hosted on servers located abroad.

\subsection{Barriers to Entrepreneurship-financial}

Venture capital for SMEs offers many benefits (Cruz and Villamil, 2000). In Cuba today, it means relying heavily on remittances from family members (and other "silent partners") overseas. Recent estimates are that between $\$ 1.5$ and $\$ 2$ billion reach islanders from the Cuban Diaspora in South Florida, Spain, and other third countries (Morales, 2009). Morales and Scarpaci (2012) document that some $\$ 37$ billion USD of cash and in-kind merchandise have reached the island between 1993 and 2010, providing a major source of capital for Cuba's mundane entrepreneurship.

In September 2010, the Cuban government announced it would provide small loans to the half a million state workers who are being laid off, and who might then seek employment as a cuentapropista (Digital Granma Internacional, 2010, Vidal and Pérez 2010). Although details remain vague some four years later, such a policy would reverse one where 
micro-enterprises traditionally did not have access to credit from the Cuban banking system. The official state newspaper and publication of the Cuban Community Party described this policy about-face this way:

"Increasing the opportunities for self-employment is one of the decisions which the country is making in terms of restructuring its economic policy, in order to increase levels of productivity and efficiency. It is also an attempt to offer workers another way of feeling useful in terms of personal effort..." (Digital Granma Internacional, 2010).

The decided policy shift to market reforms, although lukewarm, marks a long and winding course to the current day (see table 1). In turn, this may reflect an important cultural change - what the Cuban leadership has called a "change in mentality" (Castro, 2010; Peters, 2010; Peters 2000). Table 1 indicates the incremental and stop-and-go policy changes that characterize entrepreneurship on the island, and culminates with the potentially transcendental moment of President Obama's December 2014 announcement to lift the trade embargo.

\section{Table 1}

Macro-economic Policies and Consumption and in Cuba 1959-2013

\begin{tabular}{|c|c|}
\hline Period & Policies and Consumption-based Outcomes \\
\hline $1959-1961$ & $\begin{array}{l}\text { Nationalization of U.S. corporate holdings such as Esso, Texaco, Hilton, } \\
\text { Pan Am, and other multinationals. German, British, and other foreign } \\
\text { holdings are also nationalized. Agrarian reform measures limit the size } \\
\text { of farmlands and break-up sugar and tobacco lands into smaller private } \\
\text { or state holdings. Enactment of housing and property laws granting low } \\
\text { or no rent on low-income workers. State controls housing market, espe- } \\
\text { cially property 'forfeited' by émigrés. Small and medium-sized firms } \\
\text { gradually nationalized. }\end{array}$ \\
\hline \multirow[t]{3}{*}{1962} & $\begin{array}{l}\text { U.S. trade embargo imposed. Goods from the Soviet Union and Eastern } \\
\text { European members of CMEA (Council of Mutual Economic Assistance) } \\
\text { replace American consumer goods on Cuban shelves. }\end{array}$ \\
\hline & $\begin{array}{l}\text { Cuba swaps } 1,400 \text { political prisoners (Cuban-Americans) who were } \\
\text { captured at Bay of Pigs Invasion for baby food and pharmaceuticals. }\end{array}$ \\
\hline & $\begin{array}{l}\text { The ration book (libreta de abastecimiento) is introduced, providing } \\
\text { subsidized food, tobacco and rum, and personal hygiene products for } \\
\text { households. Some consumer durable goods such as fuel (charcoal, kero- } \\
\text { sene) and light bulbs are also included. }\end{array}$ \\
\hline 1968 & $\begin{array}{l}\text { The 'Revolutionary Offensive' of } 1968 \text { seizes Cuba's smallest businesses: } \\
\text { hot-dog carts, repair shops, vegetable stands, snack shops, and the like } \\
\text { were driven underground or out of business. }\end{array}$ \\
\hline
\end{tabular}




\begin{tabular}{|c|c|}
\hline Period & Policies and Consumption-based Outcomes \\
\hline Mid-1980s & $\begin{array}{l}\text { The unraveling of the Soviet and CMEA economies impact foreign } \\
\text { trade and consumption. While one ton of Cuban sugar was originally } \\
\text { exchanged for one ton of oil, these favorable terms are phased out. In the } \\
\text { mid-1980s, some market liberalizations allow craftsmen and artists to } \\
\text { sell their wares but this ends in } 1987 \text { through the 'Correcting of Mistakes' } \\
\text { policies that snuff out timid privatizations. }\end{array}$ \\
\hline 1989 & $\begin{array}{l}\text { Collapse of the Berlin Wall symbolizes a setback for communism; ratio- } \\
\text { ning tightens in Cuba. }\end{array}$ \\
\hline 1991 & $\begin{array}{l}\text { CMEA is dissolved. Trade deficits mount in Cuba. Rationing of consu- } \\
\text { mer goods and services deepens }\end{array}$ \\
\hline $\begin{array}{l}1993 \text { to } \\
\text { present }\end{array}$ & $\begin{array}{l}\text { Foreign remittances from the Cuban Diaspora gradually increase as hard } \\
\text { currency can now be used to purchase goods in non-peso stores. By } 2000 \text {, } \\
\text { remittances account for the single-largest source of hard currency, sur- } \\
\text { passing tourism. Trained professionals start to abandon state jobs to work } \\
\text { in tourism, joint-venture operations, or self-employment. }\end{array}$ \\
\hline 1994 & $\begin{array}{l}\text { The Cuban Convertible Currency (CUC) is implemented as a way to } \\
\text { capture other hard currencies. CUCs can be purchased in national pesos, } \\
\text { Euros, sterling pounds, and even dollars, but can only be used on the } \\
\text { island. It becomes one of the highest (over-valued) valued currencies in } \\
\text { the world because its exchange rate is set internally without corresponding } \\
\text { gold reserves or Central Bank guarantees. }\end{array}$ \\
\hline 1995 & $\begin{array}{l}\text { Self-employment peaks at around } 152,000 \text { workers (still less than } 2 \text { per } \\
\text { cent of labor force). Sudden crackdowns ensure by state authorities for } \\
\text { 'illicit enrichment' (enriquecimiento ilícito) }\end{array}$ \\
\hline Early 2000s & $\begin{array}{l}\text { Venezuela discounts oil for Cubans. In exchange, Cuban professionals, } \\
\text { especially health-care workers and physicians, opt for foreign service in } \\
\text { Venezuela as part of Fidel Castro and Hugo Chávez's bilateral relations } \\
\text { to strengthen socialism. By 2013, more than 3,000 Cubans are working } \\
\text { in Venezuela, and their ability to bring in consumer goods at discounted } \\
\text { or no tariffs become important in many Cuban households. Remittances } \\
\text { from Cuban workers in Venezuela, though much smaller than Cuban- } \\
\text { American aid, increase. Joint ventures decline to just over } 200 \text {. }\end{array}$ \\
\hline 2002 & $\begin{array}{l}\text { About half of the } 152 \text { sugar mills across the island are shut down for } \\
\text { inefficiency. Government policies further encourage private agricultural } \\
\text { producers to sell surplus crops in local agricultural markets (agromerca- } \\
\text { dos). Displaced sugar workers learn basic computer software skills at } \\
\text { rural technical schools, work in mills that became industrial museums, } \\
\text { or seek employment in private agriculture or tourism. }\end{array}$ \\
\hline 2004 & $\begin{array}{l}\text { Then U.S. President George W. Bush passes executive orders that limit } \\
\text { the nature of cultural (or people-to-people) travel by U.S. citizens to the } \\
\text { island. Impacts on tourist sector are considerable, resulting in a downturn } \\
\text { of hard currency receipts. }\end{array}$ \\
\hline 2004 & $\begin{array}{l}\text { Fidel Castro adopts the Euro as the preferred foreign currency. Cubans } \\
\text { using dollars are charged a } 10 \text { per cent penalty and a } 10 \text { per cent proces- } \\
\text { sing fee in an attempt to discourage use of 'green backs' (fulas). }\end{array}$ \\
\hline
\end{tabular}




\begin{tabular}{|c|c|}
\hline Period & Policies and Consumption-based Outcomes \\
\hline 2006 & $\begin{array}{l}\text { Power is transferred to Raúl Castro who promises a more 'orthodox line' } \\
\text { of socialism in directing economy. Power outages, austerity measures and } \\
\text { food scarcity increase as consumers search out goods and services in peso, } \\
\text { CUC, and black markets to satisfy consumption needs. }\end{array}$ \\
\hline 2010 & $\begin{array}{l}\text { Raúl Castro announces layoffs of some } 500,000 \text { state workers in Septem- } \\
\text { ber so the government can arrest mounting deficits, which was described } \\
\text { as 'the biggest shift toward private enterprise since the } 1960 \text { s.' }{ }^{1} \text { Workers } \\
\text { are encouraged to pursue work in the self-employment realm, where a } \\
\text { relaxing of current lays should ease the infusion of these public workers. } \\
\text { Ration-book provisions diminish further and there is official discussion } \\
\text { in the state newspaper, Granma, about eliminating the libreta. }\end{array}$ \\
\hline 2011 & $\begin{array}{l}\text { The VI Cuban Communist Party congress approves } 24 \text { more private } \\
\text { sector jobs, increasing the private sector trades to } 178 \text {. Also announces } \\
\text { the sale of private homes and automobiles, potentially providing new } \\
\text { sources of capital for budding entrepreneurs. }\end{array}$ \\
\hline $2012-2014$ & $\begin{array}{l}\text { Migration reforms allow Cubans to leave the country without a letter of } \\
\text { invitation and for } 24 \text { months, instead of } 12 \text { months, and without losing } \\
\text { their property on the island. Some analysts speculate future migrants will } \\
\text { be able to acquire U.S. residency ('green card') after } 1 \text { year and one day } \\
\text { in the U.S., learn new skills while working informally in the U.S., and } \\
\text { bring cash and entrepreneurial knowledge back to the island. }\end{array}$ \\
\hline
\end{tabular}

Sources: Compiled by the authors over a number of researches on the field between 2009 and 2014 and based on Cruz and Villamil (2000), González-Corzo and Larson (2007), Morales and Scarpaci (2012), Przeworski (1991), Scarpaci et al. (2002), Pérez-López (1995), and Peters and Scarpaci (1998).

\subsection{Political Will}

The government's principal approach to this quandary has been to attack the 'excesses' of small enterprise as counterrevolutionary (Cruz and Villamil, 2000) or more recently as a criminal manipulation of the selfemployment regulations (Comité Central del Partido Comunista de Cuba, 2013; Frank, 2013; Valdés 2013b). Many Cubans view profit making and wealth accumulation that comes with successful small business enterprise as socially offensive, even if presently necessary (RosenbergWeinreb, 2009). However, previous research does indicate that simply 'being a good neighbor' and not overtly displaying wealth can alleviate some of these concerns (Peters and Scarpaci, 1998). Straddling the line between prosperity and penury in the changing Cuban economy permeates popular culture in Cuba and abroad (Sriram et al., 2007). For example, contemporary Afro-Cuban rap groups such as Orishas, Las Krudas, and Los Aldeanos lace their music with veiled messages about the contradictions of a changing socialist system (Fernandes 2003, 2011). Such 
artistic expressions are simply too ambiguous and common for authorities to easily censure (Block, 2001).

Although Fidel Castro criticized all the reforms implemented since 1993, he viewed them as a necessary evil (Castro, 2002; Ritter, 1998). In 2005, he reflectively characterized the Cuban socialist model this way: "among all the errors we may have committed, the greatest of them all was that we believed that someone really knew something about socialism" (Frank, 2010). In a September 2010 interview with U. S. journalist Jeffrey Goldberg, Fidel Castro candidly revealed the island's imperfect economic system, when the octogenarian remarked, "the Cuban model doesn't even work for us anymore" (Goldberg, 2010). Understanding how entrepreneurship has faired over time sheds light on the Cuban model, which is our focus in the following section.

\section{Method}

We build on Peters and Scarpaci (1998) who found that cuentapropistas were making more than three times the average monthly wage in 1998, paid about 42 per cent of their gross wages for taxes and licenses, and cherished their newfound independence. Having a steady flow of cash allowed them to purchase household goods that suddenly appeared in the state and black markets. When asked about their main challenges as cuentapropistas, the most common response was "no major challenges," followed by "high taxes and licensing fees." Surprisingly, illegal shakedowns, bribes, and kickbacks were not reported by any of the 152 informants back in 1998. Rather, the inability to buy wholesale products ranked as their second concern.

Back in 1998, Peters and Scarpaci repeatedly heard stories about the seemingly arbitrary and inexact ways state inspectors determined whether legal (e.g. state-store purchased) inputs into production were used by a cuentapropista. More recently (2014), similar tales continue to unfold. A jeweler's tale reveals the logic of the inspector: if the proper receipts could not be provided for the batteries, watch bands, or faces of wristwatches, then the jeweler would be accused of purchasing the parts on the black market, which presumably is stocked by stolen items from the state or from illegally imported supplies.

In the worst of cases, the owner could be charged with "illegal enrichment" or theft of state property, both of which carry stiff fines and potential incarceration. Tales like these were echoed by a majority of the 1998 informants (Peters and Scarpaci 1998), as well as in the later two surveys discussed below. The authors heard repeated stories of self-employed workers in Havana changing their prices wildly, or failing to post 
them. When confronted, they responded to customers that because they were not state workers, they could charge whatever they wanted, and quickly change their service guarantees (watch repairers, upholsterers, and body-shop repair specialists were cited).

The method here replicates the study of Peters and Scarpaci (1998), with the aim of (1) examining the changing nature of self-employment in Cuba between 1998, 2008, and 2011; and (2) assessing the marketing and economic development strategies framing entrepreneurship over time. The Ministry of Prices and Finances denied our requests for a national sampling frame of self-employed workers. Therefore, we used snowball and convenience sampling techniques to reach the target audience. We aimed to get a variety of business types: food preparation, mechanic and electronic repairs, bed-and-breakfast establishments, book vendors, cobblers, barbers, upholsterers, and related self-employment types. These methods are appropriate when working with sensitive information and when formal sampling frames are unavailable (Babbie, 2007). Where the 1998 study drew on workers from Pinar del Río, Havana, and Havana City provinces, the 2008 and 2011 surveys excluded Pinar del Río self-employed workers.

\section{Findings}

Surveys show that self-employed Cuban workers value their independent work setting, having a steady cash flow, and co-locating work and residence. By 2008, only experienced and more educated workers had remained in this labor sector, while by 2011 the sweeping reforms, had 'opened the gates' as new and younger workers with less formal education rushed in to seek their livelihoods or strike out on their own after public downsizing (table 2). Moreover, the tax/profit percentage rose from $41 \%$ to 45\% between 1998 and 2008, reaching 47\% in the 2011 survey, which underscores the government's goal of adding to the public till through taxation.

Although the number of self-employed workers fell by about one quarter across the island between 1998 and 2008, the 2008 data profiled a slightly older, better educated, and greater compensated group of workers than a decade before. Cuentapropistas earned more than the average Cuban worker and physicians, and they were paying about 10 per cent more in taxes than those in the previous study. With the recent labor liberalization implemented in 2010, the 2011 survey reflects that as more workers entered private businesses, the formal level of schooling and the age of the entrepreneurs fell. Gross income and tax levels changed little. It is noteworthy that in 2011 there were some 340,000 valid private sec- 
Table 2

Cuban Entrepreneur Profiles, 1998, 2008 and 2011, Mean Survey Results

\begin{tabular}{lccc}
\hline \multicolumn{1}{c}{ Variable } & $1998(n=152)$ & $2008(n=154)$ & $2011(n=149)$ \\
\hline Age (years) & 43 & 45 & 39 \\
Years of schooling & 12 & 14.5 & 10.5 \\
Months in business & 28 & 37 & 22 \\
Net income (monthly) & 743 & 1157 & 1095 \\
Net income compared to & & & \\
2008 Cuban physician wage & $165 \%$ & $257 \%$ & $243 \%$ \\
(450 pesos monthly) & & & \\
Net income compared to & $347 \%$ & $386 \%$ & $257 \%$ \\
average Cuban salary & {$[212$ pesos] } & {$[300$} & {$[420$} \\
[time period mean] & & pesos] & pesos] \\
Tax/Profit percentage & $41 \%$ & $45 \%$ & $47 \%$ \\
\hline
\end{tabular}

Source: 1998 data from Peters and Scarpaci (1998); other years from the authors.

tor licenses (combining the roughly 140,000 in 2010 with the 200,000 new ones issued thereafter) as state workers anticipated downsizing and increasingly opted to get a toehold in the emerging entrepreneurial sector before being left behind (Agence France Presse, 2010).

Our concern here is to focus on a major area of distinction in relation to the question: "What principal challenge does your business face?" Five nominal response categories followed (see figure 2). Test results for 1998 data produced a Chi-square of 47.58 with five degrees of freedom $(\mathrm{p}<.001)$. The same nominal response categories for the 2008 were also significant with a Chi-square of 28.03 ( $\mathrm{p}<.001$ ); we did not ask the challenges question in 2011.

In general, entrepreneurial challenges increased between 1998 and 2008 in the realms of supplies (cost and availability), taxes and licensing fees, and inspectors and regulations. Referring to both inspection and supplies as challenges, a pizza maker/vendor in Eastern Havana stated that that when an inspector arrives at the work site, he/she immediately demands to see receipts for the inputs: flour, eggs, yeast, oil, salt, tomato sauce, and related ingredients. The pizza maker described it thus:

They quickly determine whether my retail receipts are sufficient -never mind they are expensive as all [heck] — and if the inspector doesn't believe I can document sales, I could be fined, or even shut down (authors' translation). 
Figure 2

Major challenges specified by Cuban self-employed workers: 1998-2008 and 2011

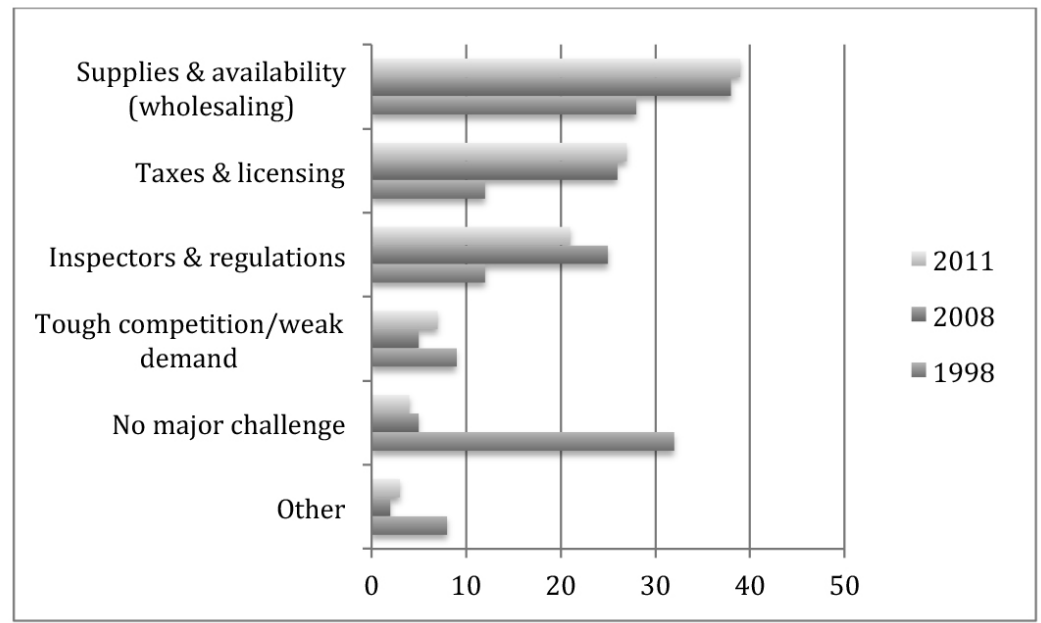

Source: Authors'data.

He ends his recounting of the matter with the popular Cuban refrain: "Esto no es fácil!" (This isn't easy!). The pizza maker, like the jeweler described above, is required to buy all his supplies at government shops that charge retail, hard-currency denominated prices. If the pizza maker wishes to add a sample sign that hangs perpendicular to the front of his restaurant (versus a sign in the window, which is free of charge), he will have to pay the municipality a fee for the advertising. Like mundane hip in the former USSR (Rehn and Taalas 2004), viral marketing and proximity between vendors and consumers drive customers to providers and remain the only marketing channels available.

\section{Discussion}

Following Drucker's (1958) call half a century earlier, this paper has attempted to isolate and analyze more closely a particular type of entrepreneur. It would appear that nearly 50 years of socialism have not diminished the yearning for self-employment, which challenges Hofstede's (2001) thinking on non-capitalist based entrepreneurship. A half a century of central planning has created an important space for these workers to provide products and services in ways that the state cannot (RosenbergWeinreb, 2009). Although there is no unequivocal evidence that small business owners are more likely to cut corners, underreport, and engage 
in 'grey' activities (e.g., buying on the black market), the temptations are many. An auto body repairman in Pinar del Río put it this way:

\footnotetext{
"We buy everything from the state, and we buy at retail. It is not fair that those [joint-venture] companies can bring everything in a large container, while we cuentapropistas are mercilessly taxed at high levels. So if some epoxy or quality paint shows up on the [underground] market, the temptation [to buy it] is great!" (Authors' notes and translation).
}

The most prominent challenge continues to be getting supplies at low prices (Cruz and Villamil, 2000; Peters and Scarpaci, 1998; Ritter, 1998). Wholesaling remains absent and distribution channels remain limited; cuentapropistas resent these constraints. Supply-chain improvements will no doubt add value to a wide array of products and services (Ritter, 1998). Until June 2012, Cubans living abroad could bring limited inputs for business production back to the island so that small businesses could use those materials; this was duty free. Prior to the new duties on entrepreneurial goods, Cubans scrambled to get supplies onto the island before the deadline.

The number of charter flights from the United States doubled on the final tax-free day; an additional ten flights carried what customs officials described mainly as food items. This reversal of import duties counters a 2008 law that allowed international passengers to enter Cuba duty-free with food if they claimed it was non-commercial reasons (Rainsford, 2012). Paladar operators must now seek pricier inputs from state stores or the black market, no doubt will have to pass those price increases on to clients. This scenario worsened considerably in 2013 when the state issued a clarification of the licenses issued to seamstresses and tailors preventing them from reselling imported clothing in the future and threatening as many as 20,000 such microenterprises with bankruptcy and closure (Valdés, 2013a; García, 2013; Gaceta Oficial de la República de Cuba, 2013).

The government also extended this "command and control" posture by outlawing the operations of the innovative entrepreneurs who had set up private $3 \mathrm{D}$ cinemas and game rooms making creative use of "operator of recreational equipment" or "paladar" licenses (Espacio Laical, 2013). Moreover, channels of advertising for Cuba's micro-entrepreneurs are confined to word-of-mouth. Internet marketing strategy is out of reach for all but the most successful cuentapropistas (Freedom House, 2013).

The second challenge is taxes and licensing fees, which has also been reported in earlier studies in Cuba (e.g. Cunha and Campos e Cunha, 2003; Suchman et al., 2001) and elsewhere (Kamleitner et al., 2012). In fact, legislation established since October 2010 require that cuentapropistas 
contribute a 25 per cent tax on monthly gross earnings to a social security pension fund. State workers do not pay this tax (Martínez and Puig, 2010). As Cruz and Villamil (2000) cautioned, this could lead to a Russian-like situation where entrepreneurs avoid all contact with the legal system (see also Yurchak 2002). However, Cuban entrepreneurs need the support of a functioning legal system (Cunha and Campos e Cunha 2003). They face stiff tax codes and harsh inspection, which is the third most prominent challenge reported in this study.

As previous literature maintains, for a truly entrepreneurial culture to exist in Cuba, a culture change of significant proportions is required (Nee and Matthews, 1996; Cruz and Villamil, 2000). Sriram et al. (2007) assert that barriers to entrepreneurship are predominated by entrepreneurial motivation and skills. In China, for example, entrepreneurship has emerged as a vital component in the Chinese economy. A shift in the view that profit making and wealth accumulation is socially offensive would be a start (Rosenberg-Weinreb, 2009). As a welder in the Alamar district of Havana reported to us in 2011; "as long as my gold chains stay under my shirt and [are] not shining in the tropical sun, I can trod along with minimal hassle from my neighbors and the inspectors". This comment may strike scholars who study entrepreneurship in market economies as trivial and banal because they fail to see the impact it has on the functioning of the enterprise. Nonetheless, functioning as an entrepreneur in Cuba necessitates the downplaying of material rewards (gold chains) and captures a central tenet of mundane or everyday entrepreneurship in Cuba; the extent to which such "bling" or ostentatious behaviors are defined remain culturally defined in time and space.

So too does sharing wealth either tangibly or intangibly among neighborhoods and engaging in neighborhood activities sponsored by the Committee for the Defense of the Revolution (CDR). This implies attending meetings and occasionally volunteering for all-night neighborhoodwatch shifts in front of state stores (that are often targeted by burglars). A shift in the position of the state would be another important step.

\section{Conclusions}

Demand for working outside the state system is unprecedented and the legalization of the sale of homes (with a $16 \%$ commission charged by the state) and private automobiles (with an $8 \%$ tax) will no doubt afford entrepreneurs with capital that is without precedent in Cuba. We contend that at least four impediments must be resolved for the entrepreneurial sector to truly come out of the shadows and contribute to economic growth.

1. The control-intensive approach that has created a list of specific permissible occupations (instead of allowing the flowering of as many 
kinds of jobs as entrepreneurs can dream up) acts as a significant brake on job creation. Such lists are too narrow to absorb the half a million downsized workers.

2. State-lending agencies may not have sufficient liquidity to provide any significant amount of capital to these new workers. Still, no plans exist for a wholesale market for self-employed workers, cooperatives, or new micro-enterprises. Instead, our preliminary fieldwork shows that remittances (and in-kind supplies) sent from abroad often constitute the required start-up capital for small businesses. This is a great irony given that despite the five-decade trade embargo that U.S. has imposed on the island, Cuban Americans can wire up to $\$ 10,000$ USD daily to family in Cuba (Morales and Scarpaci 2012; Peters 2012b).

3. There may be insufficient demand or disposable income to support these new enterprises due to the global and island-wide economic downturn.

4. Extending the categories of permitted self-employment and microenterprise may cannibalize Cuba's export of professional services, which brings in about $\$ 6$ billion USD into the economy, more than three times the amount that tourism generates (Martín, 2010). The VI Congress of the Cuban Communist Party in April 2011 signaled the government's awareness that it needs to take into account its citizens as these important changes take hold. This realignment entails the state's goals for a socialist society as defined by revolutionary ideals, and the ability to adapt to everyday material needs. However, the Cuban case departs in key ways from transitions from centrally planned economies in the former USSR and China (Liao and Sohmen 2001; Li and Matlay, 2006).

Mundane entrepreneurship in Cuba unfolds at a more guarded pace -"without haste, but without pause" in the words of Raúl Castro- than in the former USSR. SMEs remain tightly regulated; municipalities have only recently been empowered with tax-gathering benefits as in China, where the 'traditional local government' has transitioned into an 'entrepreneurial local government.' This resulted from their need for financial independence and self-sufficiency and this was set in motion by the economic reforms and fiscal decentralization that took place during the 1980s.

This has not developed in Cuba even though the literature shows that entrepreneurial behavior is not solely the domain of private businesses (Li and Matlay, 2006). Our interviews with municipal government officials (poder popular) indicate that they are interested in getting local tax revenues from entrepreneur fees and licenses to pay for mundane expenses like road repair and trash removal, without recurring to the national government through cumbersome processes.

Following Rehn and Taalas (2004), our discussion of Cuban entrepreneurship and society has focused on a command economy that we 
believe is also fundamentally an entrepreneurial society. By introducing the case of the Cuban-style blat, cuentapropismo, and newly created SMEs, the paper illustrates how mundane individual economies constitute entrepreneurship and how flexible networks complement Cuba's command economy. To exclude irregular economies such as Cuba's from broader discussions of entrepreneurial behavior may be rationalized from an ideological perspective but does not hold up from an analytic perspective.

Evidence of mundane entrepreneurship in Cuba suggests that SMEs could be important elements of change in the process of transition to a market economy and supportive elements in the development of democracy and a strong civil society (Morrison, 2000; Sriram et al., 2007). SMEs could also be framed politically as a step to perfect socialism and shed the complicated ideological baggage that the economy is moving towards capitalism (Morales, 2009).

In fact, the Cuban Communist Party "Guidelines" published in 2010 and ratified in 2011 call for the targeting of "vulnerable groups" (e.g., children, elderly, infirm, women and infants) in a way that the "Chilean miracle" did under General Augusto Pinochet in the 1980s as the socialist welfare state of that nation was being scaled back (Scarpaci 1988; Scarpaci 1989). Witness, for example, the Chinese government's official 2002 'white paper' on labor and security, in which the word 'wealth' is not mentioned a single time, yet the document heralds the average annual (1978-2001) 5\% increase in real wages (Government of China, 2002).

Cuba's mundane entrepreneurship is not antithetical to a socialist agenda, as Vietnam's trajectory shows. In a recent visit to Havana by the Vietnamese Communist Party chief, Nguyen Phu Trong, Juventud Rebel$d e$, the Cuban newspaper, lauded Vietnam's "doi moi" economic restructuring, proclaiming it a "process that contemplates introducing the logic of markets into the economy, but with a socialist orientation." Cuba's main newspaper, Granma, then ran an interview with Nguyen who claimed the Vietnamese government's main challenge was "to change the general and individual mentality in Vietnam" in the face of many who "thought that the country intended to abandon socialism." Cubans are in this "same phase," he said. History has shown that Vietnam has not abandoned socialism, he asserted, citing Vietnam's broad-based growth and poverty reduction (Peters, 2012a: 22). However these socialist economies frame these narratives, we have seen that the development of SMEs is beneficial, perhaps even essential, in transition economies for many reasons.

Unlike the blat system of the USSR, there has been no 'overnight' transition to market forces in the Caribbean nation (Dyker 2002), which begs the question: What role is there for SMEs in Cuba's entrepreneurial realignment? As Cuban workers become increasingly disassociated from 
the state, they shift from being a vehicle of the Revolution to an entity that must be regulated, scripted, and tightly controlled (Phillips, 2008: 349-350). Driving this shift is a rising political and societal acceptance of material workplace incentives over moral ones.

We argue that a central coping strategy of theirs is to drawn on lessons learned from the island's mundane entrepreneurship, which has already provided thousands of Cubans with material benefits in a society where material scarcity is rampant. Unlike the Soviet blat system, mundane capitalism in Cuba has received careful government regulation for nearly two decades and remains a keystone in the bridge for a centrally-planned economy to a mixed-market one.

The limitations of this research stem from the inability to secure a sampling frame from the Ministry of Prices and Finance. It would provide the total universe of legal self-employment across the nation's $169 \mathrm{mu}-$ nicipalities, and enable stratified sampling by sector and municipality. Greater sampling of rural, small town, and agricultural enterprises would also provide a richer dimension to mundacity and self-employment. Future research will be able to build on the tangible changes of the possible rapprochement between the U.S. and Cuba based on President Obama's late 2014 pronouncement. It should examine whether the new post-Panamax container port at Mariel Bay -just west of Havana- encourages wholesaling and invites more commercial traffic to Cuba in a post-embargo era. Research that builds on concepts such as reciprocity, the mundane, and solidarity can enhance our theorization of entrepreneurship, Cuba's economy of favors, and perhaps even enhance the workings of our own everyday economies.

\section{References}

Agence France Presse (2010), "Más de 81,000 cubanos piden permisos para abrir negocios", Cuba Verdad, November 29 $9^{\text {th }},<$ http://www. cubaencuentro.com/cuba/noticias/mas-de-81-000-cubanos-piden-permisos-para-abrir-negocios-249877>, December 27 ${ }^{\text {th }}, 2014$.

Babbie, Earl (2007), The practice of social research, Wadsworth-Thompson, Belmont.

Block, Holly (2001), Art Cuba: the next generation, H. Abrams, New York.

Castro, Fidel (2002), "The barbaric world order that humanity endures today cannot last much longer", discurso presentado el 26 de Julio de 2002 en la Plaza Revolucionaria Abel Santamaría Cuadrado, Ciego de Ávila, en el 49 aniversario del ataque contra el 
Moncada, <http://www.marxists.org/history/cuba/archive/castro/2002/07/26.htm>, December 27 $7^{\text {th }}, 2014$.

Castro, Raúl (2010), Discurso presentado en el séptimo encuentro legislativo del Poder Popular, 18 de Diciembre, <http://www.cuba. cu/gobierno/Raúldiscursos/2010/ing/r181210i.html>, December $27^{\text {th }}, 2014$.

Cepal (Economic Commission for Latin America and the Caribbean) (1997), La economía cubana: Reformas estructurales y desempeño en los noventa, Cepal-Fondo de Cultura Económica, México.

Comité Central del Partido Comunista de Cuba (2013), "Nota informativa sobre el trabajo por cuenta propia," Diario Granma, October $2^{\text {nd }}$, <http://www.granma.cubaweb.cu/2013/11/02/nacional/artic01.html>, December 27 ${ }^{\text {th }}, 2014$.

Cruz, Robert D. and A. Villamil (2000), "Sustainable small enterprise in a Cuban transition economy", Studies in Comparative International Development, 34 (4), Springer-Verlag, pp. 100-122.

Cubadebate (2014), "Trabajo por cuenta propia crece y se valida como opción de empleo en Cuba”, UCI, March 19 ${ }^{\text {th }}$, <http://www. cubadebate.cu/especiales/2014/03/19/trabajo-por-cuenta-propiacrece-y-se-valida-como-opcion-de-empleo-en-cuba/\#.VpgZa8pXuGw>, December 27 $7^{\text {th }}, 2014$.

Cunha, Miguel Pina and Rita Campos e Cunha (2003), "The interplay of planned and emergent change in Cuba", International Business Review, 12 (4), Elsevier, pp. 445-459.

Digital Granma Internacional (2010), "The self-employment sector: much more than an alternative", Partido Comunista de Cuba, October $10^{\text {th }}$, <http://www.granma.cu/ingles/cuba-i/27septiembre-3acpropia-a.html>, December $27^{\text {th }}, 2014$.

Dilla, Haroldo (2001), "Local government and economic and social change in Cuba", FOCAL: Canadian Foundation for the Americas, September $24^{\text {th }}$, <http://www.cubasource.org/pdf/socialchange. pdf $>$, December $27^{\text {th }}, 2014$. 
Drucker, Peter (1958), "Marketing and economic development", Journal of Marketing, 22 (3), American Marketing Association, Chicago, pp. 252-259.

Dyker, David (2002), Restructuring the soviet economy, Routledge, LondonNew York.

Elinson, Hannah (1999), Cuba's jineteros: youth culture and revolutionary ideology, Cuba Briefing Papers, No. 20, Trinity College, Washington.

Espacio Laical (2013), "La polémica: En torno al cierre de los cines 3D”, Centro Cultural Padre Félix Varela, La Habana, <http://www. espaciolaical.org/contens/36/128142.pdf>, pp. 128-142.

Espinosa-Chepe, Óscar and Ted A. Henken, (2013), "Economics", in Henken Ted A., Miriam Celaya and Dimas Castellanos (eds.), Cuba, in Focus, ABC-CLIO, California, pp. 135-182.

Feinberg, Richard (2013), "Soft landing in Cuba? Emerging entrepreneurs and middle classes", Brookings, Washington, <http://www. brookings.edu/ //media/Research/Files/Reports/2013/11/cuba\% 20 emerging $\% 20$ entrepreneurs $\% 20$ middle $\% 20$ classes $\% 20$ feinberg/cuba $\% 20$ entrepreneurs $\% 20$ middle $\% 20$ classes $\% 20$ feinberg.pdf>, December $27^{\text {th }}, 2014$.

Fernandes, Sujatha (2003), "Fear of a black nation: local rappers, transnational crossings, and state power in contemporary Cuba", Anthropological Quarterly, 76 (4), Questia, Cengage Learning, pp. 575-608.

Fernandes, Sujatha (2011), Close to the edge: in search of the global hip hop generation, Verso, London-Brooklyn.

Frank, Marc (2010), "Cuba’s economy at a crossroads", Financial times, The Financial Times Ltd 2015, October $5^{\text {th }}$, <http://www.ft.com/ cms/s/0/9dbb96b8-be99-11df-a755-00144feab49a.html>, December $27^{\text {th }}, 2014$.

Frank, Marc (2013), "Cuba moves to safeguard monopoly on imported goods", Reuters, September 26 ${ }^{\text {th }}$, <http://www.reuters.com/article/us-cuba-reform-idUSBRE98P0WD20130926>, December $27^{\text {th }}, 2014$. 
Freedom House (2013), "Freedom on the net: Cuba", <http://www. freedomhouse.org/sites/default/files/resources/FOTN\%20 2013_Cuba.pdf>, December 27 $7^{\text {th }}, 2014$.

Gaceta Oficial de la República de Cuba (2013), Resolución No. 353/2013, No. 41/2013 and No. 42/2013, Ministerio de Justicia, special number, No. 27 , September $26^{\text {th }}$.

García, Anne-Marie (2013), "Cuban entrepreneurs gird for ban on import sales", Associated Press, October 19 ${ }^{\text {th }}$, <http://news.yahoo.com/ cuban-entrepreneurs-gird-ban-import-sales-040325919.html, December $27^{\text {th }}>, 2014$.

Goldberg, Jonathan (2010), "Cuban model doesn't even work for us anymore", The Atlantic, October $5^{\text {th }}$, <http://www.theatlantic. $\mathrm{com} /$ international/archive/2010/09/fidel-cuban-model-doesnteven-work-for-us-anymore/62602/>, December 27 $7^{\text {th }}, 2014$.

González-Corzo, Mario and Larson, Scott (2007), "Cuba's unique remittance landscape: a comparative perspective", Journal of LatinoLatin American Studies, 2 (4), University of Nebraska, Omaha, pp. 47-73.

Gordon, Michael (1976), The cuban nationalizations: the demise of private foreign property, Hein and Company, Buffalo.

Government of China (2002), Labor and social security in China-official publications, November $2^{\text {nd }}$, <http://www.gov.cn/english/official/ 2005-07/27/content_17750.htm>, December 27 $7^{\text {th }}, 2014$.

Henken, Ted (2002), "Vale todo (anything goes): Cuba's paladares", Cuba in transition, 12, Association for the Study of the Cuban Economy, pp. 344-353.

Hernández-Reguant, Ariana (2009), "Writing the special period: an introduction", In Cuba in the Special Period: Culture and Ideology in the 1990s, Palgrave Macmillan, London, pp. 1-18.

Hofstede, Gert (2001), Culture's consequences: comparing values, behaviors, institutions and organizations across nations, Sage, Thousand Oaks.

Kamleitner, Bernadette, Christian Korunka and Erich Kirchler (2012), "Tax compliance of small business owners", International Journal 
of Entrepreneurial Behavior \& Research, 18 (3), Emerald Group Publishing, pp. 330-351.

León, Francisco (1995), "Socialismo y sociolismo: los actores sociales en la trancisión cubana", ponencia presentada en el congreso, "Toward a New Cuba: Legacies of Revolution", April $8^{\text {th }}$, New Jersey, Princeton University, Princeton.

Li, Jun and Harry Matlay (2006), "Chinese entrepreneurship and small business development: an overview and research agenda", Journal of Small Business and Enterprise Development, 13 (2), Emerald Insight, pp. 248-262.

Liao, Debbie and Philip Sohmen (2001), "The development of modern entrepreneurship in China”, Stanford Journal of East Asian Affairs, 1 (1), Spring, pp. 27-33

Leibenstein, Harvey (1968), "Entrepreneurship and development", The American Economic Review, 58 (2), American Economic Association, Nashville, pp. 72-75.

Martín, Jorge (2010), “Kaos en la red: A dónde va Cuba? Hacia el capitalismo o al socialismo?" Corriente Marxista Internacional, October $10^{\text {th }}$, <www.kaosenlared.net/noticia/donde-va-cuba-haciacapitalismo-socialismo $>$, December $27^{\text {th }}, 2014$.

Martínez, Leticia and Puig, Yaima (2010), "Más valen las cuentas claras", Diario Granma 22, Comité Oficial del Partido Comunista de Cuba, October $22^{\text {th }}$, <http://www.granma.cubaweb.cu/2010/ 10/22/nacional/artic02.html>, December $27^{\text {th }}, 2014$.

McClelland, David and Gregory Teague (1975), "Predicting risk preferences among power related tasks", Journal of Personality, 43 (2), Wiley Online Library, pp. 266-285.

Mitnick, Barry (1980), The political economy of regulation, New York, Columbia University Press.

Morales, Emilio (2009), Cuba: Una transición silenciosa al capitalismo?, Alexandria Publishers, Miami. 
Morales, Emilio and Scarpaci, Joseph (2012), Advertising without marketing: brand preference and consumer choice in Cuba, Routledge, London and Nueva York.

Morrison, Alison (2000), "Entrepreneurship: what triggers it?", International Journal of Entrepreneurial Behavior \& Research, 6 (2), Emerald Group Publishing, pp. 59-71.

Nee, Victor and Rebecca Matthews (1996), "Market transition and societal transformation in reforming state socialism", Annual Review of Sociology, 22, Nonprofit Scientific Publisher, Canadá, pp. 401-435.

ONE (Oficina Nacionales de Estadística) (2013), Tendencias de empleo (1994-2012), Cepal, La Habana.

Osborn, J. and Wenger, B. (2005), "Cuban cuentapropistas", Global Business Issues Journal, No. 3, pp. 32-39.

Pérez-López, Jorge F. (2001), "Cuba's socialist economy: the mid-1990s", in Horowitz, Irving Louis and Jaime Suchlicki (eds.), Cuban Communism, Transaction Publishers, New Brunswick, pp. 205-236.

Pérez-López, Jorge F. (1995), Cuba's second economy: from behind the scenes to center stage, Transaction Books, New Brunswick, New Jersey.

Pérez-López, Jorge F. (1994), "Islands of capitalism in an ocean of socialism: joint ventures in Cuba's development strategy", in Cuba at a Crossroads: Politics and Economics after the Fourth Party Congress, University Press of Florida, Gainesville.

Peters, Phil and Scarpaci, Joseph (1998), Five years of small-scale capitalism in Cuba, Lexington Institute, Arlington, Virginia.

Peters, Phil (2000), A policy towards Cuba that serves U.S. interests - Policy Analysis, No. 384, Cato Institute, Washington, July $13^{\text {th }}$, <http:// www.cato.org/pubs/pas/pa384.pdf>, December 27 $7^{\text {th }}, 2014$.

Peters, Phil (2010), "Be a good communist, support your local entrepreneur," The Cuban Triangle, December $20^{\text {th }}$, <http://cubantriangle. blogspot.ca/2010/12/be-good-communist-support-yourlocal. html>, December $27^{\text {th }}, 2014$. 
Peters, Phil (2012a), A viewer's guide to Cuba's economic reforms, The Lexington Institute, Arlington, Virginia, May $29^{\text {th }}$, <http://www. lexingtoninstitute.org/library/resources/documents/Cuba/ ResearchProducts/ViewersGuide.pdf>, December 27 $7^{\text {th }}, 2014$.

Peters, Phil (2012b), Cuba's Entrepreneurs: Foundation of a New Private Sector, Lexington Institute, Arlington, Virginia.

Phillips, Emma (2007), "Maybe tomorrow I'll turn capitalist: Cuentapropismo in a workers' state", Law \& Society, 41 (2), Wiley Online, pp. 305-342.

Phillips, Emma (2008), "Dollarization, Distortion, and the Transformation of Work", in M. Fount (ed.), Changing Cuba/Changing World, New York, City University of New York, Bildner Center, pp. 345-360.

Przeworski, Adam (1991), Democracy and the market: political and Economic reforms in Eastern Europe, Cambridge University Press, Cambridge.

Rainsford, Sarah (2012), “Cuba bids farewell to tax-free imports”, BBC News, La Habana, June 26 ${ }^{\text {th }}$, <http://www.bbc.co.uk/news/worldlatin-america-18525923>, December 27 ${ }^{\text {th }}, 2014$.

Rehn, Alf and Saara Taalas (2004), "Blat, the Soviet Union and mundane entrepreneurship”, Entrepreneurship \& Regional Development, 16 (3), Taylor \& Francis online, pp. 235-250.

Ritter, Arch (1974), The economic development of Revolutionary Cuba: Strategy and performance, New York, Praeger.

Ritter, Arch (1998), "Entrepreneurship, micro-enterprise, and public policy in Cuba: Promotion, containment, or asphyxiation?", Journal of Interamerican Studies and World Affairs, 40 (2), Latin American Political Society, Miami, pp. 63-94.

Ritter, Arch and Ted Henken (2014), Entrepreneurial Cuba: The Changing Policy Landscape, FirstForum Press, Boulder, Colorado.

Rosenberg-Weinreb, Amelia (2009), Cuba in the shadow of change: daily life in the twilight of the revolution, University Press of Florida, Gainesville. 
Scarpaci, Joseph (1988), Primary medical care in Chile: accessibility under military rule. University of Pittsburgh Press, Pittsburgh, Pennsylvania.

Scarpaci, Joseph (1989), Health services privatization in industrial societies, Rutgers University Press, New Brunswick and London.

Scarpaci, Joseph and Annie Hall (1995), "Cycling in Havana: 'Green' transportation by policy default", Sustainable Transport, No. 4, Institute for Transportation Policy and Sustainable Development, New York, pp. 4-6.

Scarpaci, Joseph (1995), "The emerging food and Paladar market in Havana", Cuba in Transition, No. 5, Association for the Study of the Cuban Economy, Washington, pp. 74-84.

Scarpaci, Joseph, Roberto Segre and Mario Coyula (2002), Havana: two faces of the antillean, The University of North Carolina Press, Carolina.

Scarpaci, Joseph (2002), "Havana: The dynamics of local executive power", in Myers, D. J. and H. A. Dietz (eds.), Capital City Politics in Latin America: Democratization and Empowerment, Lynne Rienner Publishers, Boulder, Colorado, pp. 163-192.

Scarpaci, Joseph (2010), "A preliminary overview of brand awareness in Cuba", ponencia presented at Association for the Study of the Cuban Economy, Miami, July $30^{\text {th }}$.

Schumpter, Joseph (1942), Capitalism, socialism and democracy, Harper, New York.

Sriram, Ven, Mersha, T. and Lanny Herron (2007), "Drivers of urban entrepreneurship: an integrative model", International Journal of Entrepreneurial Behavior \& Research, 13 (4), Emerald Insight, pp. 235-251.

Suchman, Mark C., Steward, Daniel J. and Clifford A. Westfall (2001), "The legal environment of entrepreneurship: observations on the legitimation of venture finance in Silicon Valley", in C. B. Schoonhoven and E. Romanelli (eds.), The entrepreneurship dynamic, Stanford University Press, Stanford, pp. 3015-3020. 
Trumbull, Charles (2001), "Economic reforms and social contradictions in Cuba", Cuba in transition, Association for the Study of the Cuban Economy, Washington, pp. 316-320.

Valdés, Tania (2013a), "Cuban food ration system marks 50 years amid controversy", Reuters, July $12^{\text {th }}$, <http://www.reuters.com/article/2013/07/12/us-cuba-reform-ration-idUSBRE96B0NP20130712>, December 27 ${ }^{\text {th }}, 2014$.

Valdés, Tania (2013b), "Conflict brews in Cuba over ban on sales of imported good," Reuters, October $3^{\text {rd }}$, <http://www.reuters.com/ article/cuba-reform-idUSL1N0HT1EE20131003>, December $27^{\text {th }}, 2014$.

Vidal, Pavel and Omar Pérez (2010), "Entre el ajuste fiscal y los cambios estructurales: Se extiende el cuentapropismo en Cuba", Espacio Laical, Digital Supplement, No. 112, Arquidiócesis de La Habana, La Habana, pp. 1-5.

Yurchak, Alexei (2002), "Entrepreneurial governmentality in post-socialist russia: a cultural investigation of business practices", in Boneell, V. E. and T. B. Gold (eds.), The New Entrepreneurs of Europe and Asia, M. E. Sharpe, Armonk, pp. 278-324.

Zawadski, Dennis K. (2009), "Cuban president vows to continue 'perfecting socialism”, Chicago Examiner, October 8, <http://www. examiner.com/foreign-policy-in-chicago/cuban-president-vowsto-continue-perfecting-socialism>, December $27^{\text {th }}, 2014$.

Received: September 26 $6^{\text {th }}, 2014$. Corrected: November $28^{\text {th }}, 2014$. Accepted: February $9^{\text {th }}, 2015$.

Joseph L. Scarpaci. PhD in Geography from the University of Florida; Associate professor of marketing, West College of Business; Professor emeritus, Virginia Tech, Blacksburg, USA. Scarpaci is Executive Director of the Center for the Study of Cuban Culture and Economy in Blacksburg, VA, USA. He coauthored of "Marketing without advertising: Brand preference and consumer choice in Cuba", Routledge, (2011); coauthored, "Engineering paradise: marketing the Dominican Republic's last frontier", in Brunn, Stan and Woods, Andrew (eds.), Engineering the 
earth: the impacts of megaengineering projects, Routledge, Boston (2011); he coproduced the short documentary Soy cubana, which premiered at the Santa Barbara International Film Festival in early 2016.

Ted A. Henken. PhD Latin American Studies from Tulane University. He is a tenured Associate Professor of Sociology with a joint appointment in the Department of Black and Latino Studies at Baruch College, City University of New York. Henken currently serves as President ex-officio of the Association for the Study of the Cuban Economy (ASCE, 20142016) after having served as President of ASCE from 2012-2014. Henken specializes in courses on contemporary Cuban culture and society, sociology of the Internet, contemporary Latin America, Latinos in the U.S., racism and ethnic relations, the sociology of religion, international migration, and comparative urban studies courses on Havana, New York, and New Orleans. Henken's newest book, coauthored, Entrepreneurial Cuba: The Changing Policy Landscape, Americas Society-Council of the Americas (2015); Chapters in books: coauthored, "Entrepreneurial reform, market expansion and political engagement: risks and opportunities for Cuba today", in U.S. Cuban Relations: Impacts on the Island and Beyond, Palgrave Macmillan (2016); coauthored, "Cyberspace to public space? The emergent blogosphere and Cuban civil society", in Brenner, Philip; Jiménez, Marguerite Rose; Kirk, John M.; and LeoGrande, William M.; The Revolution under Raúl Castro: a contemporary Cuba reader, Lanham, MD: Rowman and Littlefield, pp. 99-110 (2015); papers, coauthored, "Overcoming Cuba's internal embargo", Current History, volume 114, pp. 73-76 (2015).

Archibald R. M. Ritter. PhD in Economics, University of Texas at Austin; distinguished researcher-professor in the Department of Economics and the Norman Paterson School of International Affairs at Carleton University, Ottawa, Canada. He was an initiator and coordinator on the Canadian side of the Master's degree in Economics, program provided with the University of Havana for young Cuban professors from 1994 to 1999. His publications on Cuba include The Economic Development of Revolutionary Cuba: Strategy and Performance, Praeger, New York (1974); coauthor of Entrepreneurial Cuba: the changing policy landscape, Lynne Rienner Publishers, Colorado (2014); with other authors, he is currently working on a textbook entitled African Economic Development, Routledge Publishers, United Kingdom. He is the author of the Research Blog entitled "TheCubanEconomy/LaEconomiaCubana", <http://the cubaneconomy.com/>. 